\title{
Combining Ability for Yield and its Components in Diallel Crosses of Cotton
}

\author{
Remzi EKİNCİ*, Sema BAŞBAĞ \\ University of Dicle, Faculty of Agriculture, Department of Field Crops, 21100 Diyarbakir, Turkey; \\ remzi.ekinci@dicle.edu.tr (*orresponding author)
}

\begin{abstract}
One of the objectives of this study was to estimate gene action and the type of inheritance of investigated traits in cotton. Another objective was to evaluate general combining ability of parents and special combining ability of $F_{1}$ diallel crosses and to select the superior $F_{1} s$ that can be used in future breeding programs of cotton. Additive and dominant components were found significant for investigated traits. Number of bolls and lint percentages were effective in the control of additive type of gene action with partial dominance, but seed-cotton yield was also effective in the control of additive type of gene action with over-dominance. Greater parents were 'Paum-15' and 'Stoneville453 ' for the number of bolls and the seed-cotton yield; 'Stoneville-453' and 'Nazilli-84S' for the lint percentage. Greater cross combinations were 'Paum-15' x 'Stoneville-453'; 'Stoneville-453' x 'Nazilli-84S'; 'Stoneville-453' x 'Fantom'; 'Stoneville-453' x 'Delcerro' and 'Stoneville453 x ' 'Giza-45' diallel crosses for the number of bolls; 'Paum-15' x 'Nazilli-84S', 'Stoneville-453' x 'Fantom', 'Nazilli-84S' x 'Delcerro' and 'Nazilli-84S’ x 'Giza-45' diallel cross for the lint percentage, 'Paum-15' x 'Stoneville-453', 'Paum-15' x 'Nazilli-84S', 'Stoneville-453' x 'Nazilli84S', 'Stoneville-453' x 'Fantom', 'Stoneville-453' x 'Delcerro', 'Stoneville-453' x 'Giza-45', 'Nazilli-84S' x 'Fantom' and 'Nazilli-84S' x 'Delcerro' diallel crosses for the seed-cotton yield.
\end{abstract}

Keywords: cotton, diallel analysis, yield, yield component

\section{Introduction}

Improvement in textile processing has led to increasing emphasis on the new cotton breeding programs. Breeders of cotton are principally interested in improving the genetic potential of their materials to maximize economic gain. Genetically distant cotton genotypes may be utilized in the cotton improvement programs for higher seed-cotton yield and its components. Ecological adaptation of a genotype is an important factor in choosing parents; one parent needs to be a well-adapted genotype from the location in which it is grown (Meredith and Brown, 1998). Cheatham et al. (2003) reported that the Australian cotton genotypes and wild cotton genotypes produce the genes to improve seed-cotton yield. Previous studies also showed that variation in seedcotton yield and its components was influenced by additive and non-additive gene actions. Information regarding genetic variability for yield and its components provides suitable tools to the breeder for crop improvement.

Number of bolls and lint percentage are important seed cotton yield components. The cotton genotypes can be improved for the mentioned trait and maintained in progenies of desirable crosses.

Additive-dominance model can direct plant breeder about the validation of data and design as well as the utilization of data. The diallel analysis method can be used to estimate gene action and type of inheritance. GCA and SCA can be used in both self and cross-pollinated plants. Thus, crossing in a diallel mating design is the dependable and effective technique for the identification and choice of superior genotypes (Khan et al., 2009). The utilization of genetic information in the development of an efficient breeding program has been advocated by a large number of eminent scientists such as Hayman (1954a, 1954b), Mather and Jinks (1982), Mei et al. (2006), Wu et al. (2006), Khan et al. (2007), Aguiar et al. (2007), Khan et al. (2011), Khan (2013a, 2013b), Simon et al. (2013), EL-Refaey and Abd El-Razek (2013).

Combining ability describes the breeding value of parental genotypes to produce hybrids. Significant GCA is indicating role of additive gene action while, significant SCA is indicating the role of non-additive gene action. Bhardwaj and Kapoor (1998) revealed that seed-cotton yield and lint percentage were controlled by additive genetic variance and non-additive genetic variance.

The aim of this study was to estimate gene action and the type of inheritance of investigated traits in cotton, evaluate GCA of parents and SCA of $F_{1}$ diallel crosses, and select the superior $F_{1}$ diallel crosses that can be used in breeding program of cotton.

\section{Materials and methods}

Six diverse cotton genotypes; 'Paum-15', 'Stoneville453', 'Nazilli-84S', 'Fantom', 'Delcerro' and 'Giza-45', were selected and crossed in all feasible combinations to produce their $15 \mathrm{~F}_{1}$ diallel crosses. Although 'Paum-15' and 'Stoneville-453' have an important feature in terms of seed 
cotton yield, 'Delcerro' and 'Giza-45' have an important feature in terms of fiber quality. 'Nazilli- $84 S$ ' is an important feature in terms of lint percentage and 'Fantom' is an important feature in terms of earliness and seed cotton yield. The experiment was performed at GAP Agricultural Research and Education Center during 2010 and 2011. Six cotton genotypes were crossed in a half diallel design in 2010. The average annual rainfall over the previous 20 years was $453.6 \mathrm{~mm}$, with most of the rainfall occurring in October to April and low rain falls in July to August (data obtained from the Turkish State Meteorological Service).

\section{Traits measurement and statistical analysis}

Six parents and $15 \mathrm{~F}_{1}$ diallel crosses were planted in the randomized complete block, designed with three replicates at the same experimental area in 2011. Each plots contained two rows of $12 \mathrm{~m}$ in length at planting and $10 \mathrm{~m}$ in length at harvest. The distance between and within the row spacing was $0.70 \mathrm{~m}$. and $0.20 \mathrm{~m}$., respectively. $15 \mathrm{~F}_{1}$ diallel crosses and 6 parents were handed own in a randomized complete block (RCB) designed during crop season 2011; all plots were fertilized with $120 \mathrm{~kg} \mathrm{ha}^{-1} \mathrm{~N}$ and $60 \mathrm{~kg} \mathrm{ha}^{-1} \mathrm{P}_{2} \mathrm{O}_{5}$. Half of the $\mathrm{N}$ and all $\mathrm{P}_{2} \mathrm{O}_{5}$ were applied at sowing time and the remaining $\mathrm{N}$ was given at the squaring stage as ammonium nitrate. The experiment was thinned and hoed twice by hand and three times with machine, while herbicides (active ingredient is trifluarin) were used only once before sowing. Insects were monitored throughout the experiment and an insect control was not needed during cotton growing season. The experimental plots were irrigated seven times by furrow, first irrigation was done on the $25^{\text {th }}$ of June, and repeatedly six times at ten or twenty days intervals, totally $750 \mathrm{~mm}$ water were applied. The plots were harvested by hand for yield determination first in the $10^{\text {th }}$ of October and second on the $12^{\text {th }}$ of November. The seed-cotton yields were calculated based on the hand-harvest date.

Data were recorded on ten randomly selected plants per row in each of the three replicates as the number of bolls (number.plant ${ }^{-1}$ ), lint percentage (\%) and seed-cotton yield $\left(\mathrm{kg} \cdot \mathrm{ha}^{-1}\right)$. The boll samples were collected from the first positions of fruiting branches of the bottom (1st), middle $\left(6^{\mathrm{th}}\right)$, and top $\left(11^{\mathrm{th}}\right)$ of each sampled plant from the rows.

\section{Diallel analyses}

Analysis of $6 \times 6$ half diallel crosses was done by using a software Dial-98 (Ukai, 2006). The theory of diallel was developed by Hayman (1954a, 1954b), Hayman (1958) and Jinks (1954) and was applied by Whitehouse et al. (1958) and Mather and Jinks (1971, 1977 and 1982). All the data were subjected to analysis of variance (ANOVA) technique using JMP 5.0.1 computer software for all the traits to test the null hypothesis of no differences between various $F_{1}$ crosses and their parental lines. Estimates of both GCA and SCA were computed according to (Griffing, 1956) designated Method-II and Model-I. Diallel theory was developed by Hayman (1954a, 1954b) using Mather's concept of D, $\mathrm{H}_{1}$, $\mathrm{H}_{2}, \mathrm{~F}, \mathrm{E}, \sqrt{\frac{H 1}{D}}, \mathrm{H}_{2} / 4 \mathrm{H}_{1}, \mathrm{KD} / \mathrm{KR}, \mathrm{h}^{2} / \mathrm{H}_{2}$, r components of variation for additive and dominance variances, respectively. Mather and Jinks (1982) have described the recent development about this technique in detail.

The data for each measurement was tabulated and analyzed on plot mean basis. The diallel analysis was used to evaluate traits that had a significant variation among parents. Simple additive-dominance model approach (Hayman, 1954, 1958) modified by Mather and Jinks (1982) was followed for genetic analysis and for estimation of the components of genetic variation. The significance of components of variation in $F_{1}$ diallel crosses was tested by Jinks (1956); Hayman (1958); when the value of a parameter divided by its standard error, exceeded 1.96, then it was accepted as statistically significant.

\section{Results and discussions}

Variance between $F_{1}$ diallel crosses for all the investigated traits reveals that there are significant differences in the level of 0.01 (data not shown). The results suggest a sufficient variability in the genetic material. According to the analysis of variance of $\mathrm{Wr}-\mathrm{Vr}$, there are no significant variances of all the investigated traits (data not shown). These results reveal that assumptions adopted to evaluate the right way of diallel analysis, are valid. Regression coefficients $\left(\mathrm{b}_{\mathrm{Wr} / \mathrm{Vr}}\right)$ determined for each traits in each block are not equal to 1 which is noteworthy (data not shown). F values of (Wr-Vr) are not significant in all traits investigated. The situation exhibits that the assumptions, which are accepted to examine the analysis of diallel crosses, are correct and additive-dominance model was found adequate for all investigated traits.

Values of GCA/SCA, mean square of GCA and SCA of the investigated traits are given in Table 1 .

In Table 1, the mean squares of GCA and SCA of all the investigated traits are significant. Moreover, values of the GCA/SCA of all investigated traits were greater than 1 (Table 1). The GCA and SCA of all investigated traits have a significant difference, indicating that both additive and dominant variances in population are important. These results support the findings of Ahuja and Tuteja (2000), Tuteja et al. (2003), Mert et al. (2003), El-Mansy et al. (2010). The values of GCA/SCA of bolls per plant and lint percentage traits are greater than 1 , showing that additive effect is higher than dominant effect. These findings support the findings of Miller and Marani (1963); Baker and Verhalen (1975). The value of GCA/SCA of seed-cotton yield is greater than 0 , but not greater than 1 , showing that dominant effect is higher than additive effect.

The means of the number of bolls, lint percentage and Table 1. Values of GCA/SCA, mean square of GCA and SCA of investigated traits

\begin{tabular}{lcccc}
\multicolumn{1}{c}{ Traits } & Generations & GCA & SCA & GCA/SCA \\
\hline Bolls Per Plant plant & $\mathrm{F}_{1}$ & $243.70^{* *}$ & $5.82^{* *}$ & 41.85 \\
\hline Lint Percentage & & $109.88^{* *}$ & $3.73^{*}$ & 29.45 \\
Seed-Cotton Yield & & $393.52^{* *}$ & $623.72^{* *}$ & 0.63 \\
\hline
\end{tabular}

${ }^{*} \mathrm{p}<0.05,{ }^{* *} \mathrm{p}<0.01$ 
seed-cotton yield of the 6 parental genotypes and the $15 \mathrm{~F}_{1}$ diallel crosses (hybrids populations) are presented in Table 2.

The parental averages of the number of bolls ranged from 12.33 number.plant ${ }^{-1}$ ('Giza-45') to 27.00 number.plant ${ }^{-1}$ ('Stoneville-453') with an average of 19.28 number.plant ${ }^{-1}$. The crosses' averages of the number of bolls ranged from 12.33 number.plant ${ }^{-1}$ ('Delcerro' x 'Giza-45') to 28.53 number.plant ${ }^{-1}$ ('Paum-15' x'Stoneville-453') with an average of 20.06 number.plant ${ }^{-1}$. The parental means of lint percentage ranged from $35.74 \%$ ('Giza- 45 ') to $44.66 \%$ ('Nazilli$84 S^{\prime}$ ) with an average of $39.10 \%$, the crosses' means of lint percentage ranged from $33.07 \%$ ('Paum-15' x 'Giza-45') to 43.08\% ('Stoneville-453' x 'Nazilli-84S') with an average of $39.11 \%$. The parental means of seed-cotton yield ranged from 3377.0 kg.ha ${ }^{-1}$ ('Nazilli$84 S^{\prime}$ ) to $4357.00 \mathrm{~kg}^{2} \mathrm{ha}^{-1}$ ('Stoneville-453') with an average of $3872.00 \mathrm{~kg} . \mathrm{da}^{-1}$, the crosses' means of seedcotton yield ranged from $3400.30 \mathrm{~kg} \cdot \mathrm{ha}^{-1}$ ('Nazilli-84S' $x$ 'Giza-45') to 4575.80 kg.ha' ${ }^{-1}$ ('Paum-15' x 'Stoneville-453') with an average of $4073.50 \mathrm{~kg} \cdot \mathrm{ha}^{-1}$.

The GCA effect of the 6 parental genotypes and SCA effect of $15 F_{1}$ diallel crosses for the investigated traits are given in Table 3.

Positive and significant GCA effects were obtained for the 'Paum-15' and 'Stoneville-453' for the number of bolls, 'Stoneville-453' and 'Nazilli-84S' parents for the lint percentage, and 'Paum-15' and 'Stoneville453' parents for seed-cotton yield. The parental genotype, 'Paum-15' may be used as breeding material for the improvement of number of bolls and seedcotton yield. The parental genotype, 'Stoneville-453' may be used as breeding material for the improvement of all investigated trait. 'Nazilli-84S' may be used as breeding material for improvement of lint percentage.

Positive and significant SCA effects were obtained for 'Paum-15' x 'Stoneville-453'; 'Stoneville-453' x 'Nazilli-84S'; 'Stoneville-453' x 'Fantom'; 'Stoneville453'x 'Delcerro' and 'Stoneville-453' x 'Giza-45' diallel crosses for the number of bolls, 'Paum-15' x 'Nazilli-84S', 'Stoneville-453' x 'Fantom', 'Nazilli-84S' $x$ 'Delcerro' and 'Nazilli-84S' x 'Giza-45' diallel crosses for the lint percentage, 'Paum-15' x 'Stoneville-453', 'Paum-15' x 'Nazilli-84S', 'Stoneville-453' x 'Nazilli$84 S^{\prime}$, 'Stoneville-453' x 'Fantom', 'Stoneville-453' x 'Delcerro', 'Stoneville-453' x 'Giza-45', 'Nazilli-84S' x 'Fantom' and 'Nazilli-84S' x 'Delcerro' diallel crosses for the seed-cotton yield. The crosses 'Paum-15' $\mathrm{x}$ 'Stoneville-453'; 'Stoneville-453' x 'Nazilli-84S'; 'Stoneville-453' x 'Fantom'; 'Stoneville-453' x 'Delcerro' and 'Stoneville-453' x 'Giza-45' can be considered as greater combinations for the number of bolls; 'Paum-15' x 'Nazilli-84S', 'Stoneville-453' x 'Fantom', 'Nazilli-84S' x 'Delcerro' and 'Nazilli-84S' x 'Giza-45' diallel crosses for lint percentage; 'Paum-15' x 'Stoneville-453', 'Paum-15' x 'Nazilli-84S', 'Stoneville-453' x 'Nazilli-84S', 'Stoneville-453' x 'Fantom', 'Stoneville-453' x 'Delcerro', 'Stoneville453' x 'Giza-45', 'Nazilli-84S' x 'Fantom' and 'Nazilli$84 S^{\prime} \times$ 'Delcerro' diallel cross for the seed-cotton yield.

The diallel analysis of variance of the $F_{1}$ crosses are shown in Table 4. The analysis of variance for the number of bolls, lint percentage and seed-cotton yield in $\mathrm{F}_{1}$ crosses of the diallel showed that $\mathrm{a}$ and $\mathrm{b}$ items were highly significant, so they show presence of additive and dominance effects. The $b_{1}$ item was significant in $F_{1}$ generation for all traits (except lint

Table 2. The means of investigated traits of the 6 parental genotypes and the $15 \mathrm{~F}_{1}$ diallel crosses

\begin{tabular}{|c|c|c|c|c|}
\hline Parents/ Crosses & Genotypes & Bolls Per Plant & Lint Percentage (\%) & Seed-Cotton Yield $\left(\mathrm{kg} \cdot \mathrm{ha}^{-1}\right)$ \\
\hline \multirow{6}{*}{ Parents } & 'Paum-15' & $21.67 \mathrm{~b}$ & $36.27 \mathrm{bc}$ & $4135.9 \mathrm{~b}$ \\
\hline & 'Stoneville-453' & $27.00 \mathrm{a}$ & $42.22 \mathrm{a}$ & $4357.1 \mathrm{a}$ \\
\hline & 'Nazilli-84S’ & $19.00 \mathrm{c}$ & $44.66 \mathrm{a}$ & 3707.73 \\
\hline & 'Fantom' & $18.67 \mathrm{c}$ & $37.23 \mathrm{bc}$ & $3878.9 \mathrm{c}$ \\
\hline & 'Delcerro' & $17.00 \mathrm{c}$ & $38.46 \mathrm{~b}$ & $3778.1 \mathrm{c}$ \\
\hline & 'Giza-45’ & $12.33 \mathrm{~d}$ & $35.74 \mathrm{c}$ & $3377.9 \mathrm{~d}$ \\
\hline \multirow{14}{*}{ Crosses } & 'Paum-15'x 'Stoneville-453' & $28.53 \mathrm{a}$ & $40.02 \mathrm{~cd}$ & $4575.8 \mathrm{a}$ \\
\hline & 'Paum-15' x 'Nazilli-84S' & 20.83 de & $42.15 \mathrm{ab}$ & $4062.2 \mathrm{f}$ \\
\hline & 'Paum-15' x 'Fantom' & $22.00 \mathrm{~d}$ & $36.05 \mathrm{f}$ & $4228.3 \mathrm{e}$ \\
\hline & 'Paum-15' x 'Delcerro' & $20.00 \mathrm{ef}$ & $36.06 \mathrm{f}$ & $4092.0 \mathrm{f}$ \\
\hline & 'Paum-15’ x 'Giza 75’ & $18.33 \mathrm{gh}$ & $33.07 \mathrm{~g}$ & $4356.7 \mathrm{~d}$ \\
\hline & 'Stoneville-453' x 'Nazilli-84S' & $25.33 \mathrm{bc}$ & $43.80 \mathrm{a}$ & $4258.3 \mathrm{e}$ \\
\hline & 'Stoneville-453’ x 'Fantom’ & $26.00 \mathrm{~b}$ & $41.79 \mathrm{bc}$ & $4416.3 \mathrm{c}$ \\
\hline & 'Stoneville-453’ x 'Delcerro' & $24.48 c$ & $40.04 \mathrm{~cd}$ & $4449.6 \mathrm{bc}$ \\
\hline & 'Stoneville-453’ x ‘Giza-45’ & $21.26 \mathrm{de}$ & $39.08 \mathrm{de}$ & $4473.3 \mathrm{~b}$ \\
\hline & 'Nazilli-84S’ x 'Fantom' & $18.90 \mathrm{fg}$ & $41.07 \mathrm{bc}$ & $3892.4 \mathrm{~g}$ \\
\hline & 'Nazilli-84S’ x ‘Delcerro' & $17.00 \mathrm{~h}$ & $41.74 \mathrm{bc}$ & $3789.4 \mathrm{~h}$ \\
\hline & 'Nazilli-84S’ x ‘Giza-45’ & $13.50 \mathrm{ij}$ & $42.31 \mathrm{ab}$ & $3400.3 \mathrm{k}$ \\
\hline & 'Fantom'x 'Delcerro' & $17.97 \mathrm{gh}$ & $37.22 \mathrm{ef}$ & $3900.0 \mathrm{~g}$ \\
\hline & 'Fantom' x 'Giza-45’ & $14.37_{1}$ & $36.10 \mathrm{f}$ & $3642.6 \mathrm{i}$ \\
\hline Means of Parents & & 19.28 & 39.10 & 3872.0 \\
\hline Means of Crosses & & 20.06 & 39.11 & 4073.5 \\
\hline $\mathrm{LSD}_{0.05}$ Parents & & 2.10 & 2.44 & 202.3 \\
\hline $\mathrm{LSD}_{0.05}$ Crosses & & 1.46 & 1.98 & 52.3 \\
\hline
\end{tabular}


Table 3. GCA for the investigated traits in cotton parents and SCA for the investigated traits in cotton $\mathrm{F}_{1}$ diallel crosses

\begin{tabular}{|c|c|c|c|c|}
\hline GCA/SCA & Genotypes & Bolls Per Plant & Lint Percentage & Seed-Cotton Yield \\
\hline \multirow{6}{*}{ GCA } & 'Delcerro' & $1.77^{* *}$ & $-1.73^{* *}$ & $18.40^{* *}$ \\
\hline & 'Stoneville-453' & $5.09^{* *}$ & $1.93^{* *}$ & $34.66^{* *}$ \\
\hline & 'Nazilli-84S’' & $-0.66^{* *}$ & $3.33^{* *}$ & $-24.45^{* *}$ \\
\hline & 'Fantom' & -0.29 & $-0.88^{* *}$ & 3.46 \\
\hline & 'Delcerro' & $-1.64^{* *}$ & $-0.71^{* *}$ & -9.45 \\
\hline & 'Giza-45’ & $-4.30^{* *}$ & $-1.94^{* *}$ & $-15.69^{* *}$ \\
\hline \multirow{15}{*}{ SCA } & 'Delcerro' x 'Stoneville-453' & $1.82^{* *}$ & 0.72 & $2.88^{*}$ \\
\hline & ‘Delcerro’ x ‘Nazilli-84S’ & -0.12 & $1.44^{*}$ & $10.63^{* *}$ \\
\hline & 'Delcerro' x 'Fantom’ & 0.67 & -0.44 & 6.25 \\
\hline & 'Delcerro' x 'Delcerro' & 0.02 & -0.61 & -1.39 \\
\hline & 'Delcerro’ x ‘Giza-45’ & 1.02 & -2.35 & 31.31 \\
\hline & 'Stoneville-453' x 'Nazilli-84S' & $1.06^{*}$ & -0.57 & $13.98^{* *}$ \\
\hline & 'Stoneville-453’ x 'Fantom’ & $1.35^{* *}$ & $1.63^{*}$ & $8.80^{*}$ \\
\hline & 'Stoneville-453' x 'Delcerro' & $1.18^{*}$ & -0.28 & $18.11^{* *}$ \\
\hline & ‘Stoneville-453’ x ‘Giza-45’ & $0.62^{* *}$ & -0.01 & $26.72^{*}$ \\
\hline & 'Nazilli-84S’ x ‘Fantom' & 0.008 & -0.48 & $15.52^{* *}$ \\
\hline & 'Nazilli-84S’ x 'Delcerro' & -0.55 & $0.735^{*}$ & $11.20^{* *}$ \\
\hline & 'Nazilli-84S’ x ‘Giza-45’ & -1.38 & $1.82^{*}$ & $-21.47^{* *}$ \\
\hline & 'Fantom'x 'Delcerro' & 0.04 & -0.3 & 1.28 \\
\hline & 'Fantom’ x ‘Giza-45’ & $-0.89^{* *}$ & -0.17 & $-18.23^{* *}$ \\
\hline & 'Delcerro’ x 'Giza-45’ & $-1.57^{*}$ & -0.34 & $-19.35^{* *}$ \\
\hline SE Parents & & 0.176 & 0.234 & 1.191 \\
\hline SE Crosses & & 0.483 & 0.641 & 3.271 \\
\hline SE: Standard Error & & & & \\
\hline
\end{tabular}

Table 4. The diallel analysis of variance of the $\mathrm{F}_{1}$ crosses

\begin{tabular}{ccccc}
\hline Items & D.F. & Bolls Per Plant & Lint Percentage (\%) & Seed-Cotton Yield \\
\hline $\mathrm{a}$ & 5 & $243.7^{* *}$ & $109.89^{* *}$ & $11928.43^{* *}$ \\
$\mathrm{~b}$ & 15 & $5.82^{* *}$ & $3.73^{* *}$ & $1229.63^{* *}$ \\
$\mathrm{~b}_{1}$ & 1 & $7.77^{* *}$ & $1.04^{\mathrm{NS}}$ & $5209.5^{*}$ \\
$\mathrm{~b}_{2}$ & 5 & $14.66^{* *}$ & $3.66^{\mathrm{NS}}$ & $1096.37^{* *}$ \\
$\mathrm{~b}_{3}$ & 9 & $0.7^{\mathrm{NS}}$ & $4.18^{*}$ & $861.4^{* *}$ \\
Error & 40 & 0.89 & 1.57 & 40.86 \\
\hline NS. Non-significant $(\mathrm{p}>0.05),{ }^{*} \mathrm{p}<0.05^{* *} \mathrm{p}<0.01$ & & &
\end{tabular}

Table 5. Genetic components of variation for various traits in diallel crosses

\begin{tabular}{|c|c|c|c|c|}
\hline \multirow{2}{*}{$\begin{array}{l}\text { Genetic Components } \\
\text { D }\end{array}$} & Number of Bolls & Lint Percentage & \multicolumn{2}{|c|}{ Seed-Cotton Yield } \\
\hline & $23.57 \pm 2.33^{* *}$ & $12.29 \pm 2.196^{* *}$ & 1160.58 & $\pm 90.239^{* *}$ \\
\hline $\mathrm{H}_{1}$ & $8.92 \pm 1.64^{* *}$ & $4.21 \pm 1.463^{*}$ & 1584.55 & $\pm 108.978^{* *}$ \\
\hline $\mathrm{H}_{2}$ & $4.77 \pm 0.89^{* *}$ & $3.21 \pm 1.096^{*}$ & 1266.33 & $\pm 81.673^{* *}$ \\
\hline $\mathrm{F}$ & $-19.46 \pm 1.28^{* *}$ & $-7.21 \pm 1.481^{* *}$ & -859.68 & $\pm 62.136^{* *}$ \\
\hline$h^{2}$ & $1.54 \pm 0.99$ & $-0.25 \quad \pm 0.357$ & 1120.82 & $\pm 152.759^{* *}$ \\
\hline E & $0.27 \pm 0.05^{* *}$ & $0.49 \pm 0.078^{* *}$ & 9.18 & $\pm 1.531^{* *}$ \\
\hline$\left(\mathrm{H}_{1} / \mathrm{D}\right)^{1 / 2}$ & 0.61 & 0.58 & \multicolumn{2}{|c|}{1.17} \\
\hline $\mathrm{KD} / \mathrm{KR}$ & 0.19 & 0.33 & \multicolumn{2}{|c|}{0.52} \\
\hline $\mathrm{K}=\mathrm{h}^{2} / \mathrm{H}_{2}$ & 0.32 & -0.08 & \multicolumn{2}{|c|}{0.88} \\
\hline $\mathrm{H}_{2} /\left(4\left(\mathrm{H}_{1}\right) \quad \mathrm{uv}\right.$ & 0.13 & 0.19 & \multicolumn{2}{|c|}{0.20} \\
\hline $\mathrm{D}-\mathrm{H}_{1}$ & 14.65 & 8.08 & \multicolumn{2}{|c|}{-423.97} \\
\hline$h^{2} n^{1}$ & 0.44 & 0.48 & \multicolumn{2}{|c|}{0.32} \\
\hline$h^{2} b^{2}$ & 0.94 & 0.88 & \multicolumn{2}{|c|}{0.78} \\
\hline $\mathrm{r}(\mathrm{Yr},(\mathrm{Wr}+\mathrm{Vr}))$ & -0.69 & -0.95 & \multicolumn{2}{|c|}{-0.82} \\
\hline
\end{tabular}


Table 6. Closest position to the origin and dominance proportion of different parents for investigated traits in a $6 \times 6 \mathrm{~F}_{1}$ diallel crosses

\begin{tabular}{ccccccc}
\hline \multirow{2}{*}{ Genotypes } & \multicolumn{2}{c}{ Number of Bolls } & \multicolumn{2}{c}{ Lint Percentage } & \multicolumn{2}{c}{ Seed-Cotton Yield } \\
\cline { 2 - 7 } & DP & CP & DP & CP & DP & CP \\
\hline 'Paum-15' & 0.22 & 20.06 & -0.22 & 14.57 & 0.67 & 574.57 \\
'Stoneville-453' & 0.63 & 11.69 & 0.64 & 6.14 & 0.87 & 191.61 \\
'Nazilli-84S' & -0.01 & 24.58 & 0.82 & 4.37 & 0.09 & 1683.63 \\
'Fantom' & -0.01 & 24.62 & 0.20 & 10.46 & 0.40 & 1086.48 \\
'Delcerro' & 0.17 & 20.92 & 0.32 & 9.33 & 0.30 & 1276.59 \\
\hline 'Giza-45' & -0.03 & 24.97 & -0.27 & 15.13 & -0.28 & 2423.63 \\
\hline Means & 0.16 & 21.14 & 0.25 & 10.00 & 0.34 & 1206.09 \\
\hline
\end{tabular}

CP: Closest position to the origin $=\sqrt{W r^{2}+V r^{2}}$

DP: dominance proportion

percentage) showed that the presence of directional dominance effects were. The $b_{2}$ item was significant in $\mathrm{F}_{1}$ generation for all traits (except lint percentage) showed that the symmetrical distribution of genes were. The $b_{3}$ item was significant in $F_{1}$ generation for lint percentage and seed-cotton yield showed that specific gene effects were.

Genetic components of variation for the investigated traits in diallel crosses are given in $\mathrm{Tab}$ 5. Closest position to the origin and dominance proportion of different parents for investigated traits in a $6 \times 6 F_{1}$ diallel crosses is given in Table 6 .

\section{Number of bolls}

Number of bolls per plant is an important yield component. Considering the genetic components of variance in $\mathrm{F}_{1}$ crosses, bolls per plant revealed that additive (D) and dominance $\left(\mathrm{H}_{1}\right.$ and $\left.\mathrm{H}_{2}\right), \mathrm{F}$ and environmental (E) component of variation were significant, while $h^{2}$ was not significant (Table 5). Additive component (D) exceeded dominance components $\left(\mathrm{H}_{1}\right.$ and $\left.\mathrm{H}_{2}\right)$. D- $\mathrm{H}_{1}$ value was 14.65 and GCA/SCA value was 41.85 (Table 1) confirming the hypothesis that the additive component is more dominant than the dominance component. Similar findings were reported in cotton by Baloch, (1995), Rady et al. (1999), Bhardwaj and Kapoor (1998), Leidi (2003). The average degree of dominance $\left(\sqrt{H_{1 / D}}=0.61\right)$ was being less than 1 , suggesting partial dominance with additive type of gene action. Significant negative value of F (-19.46 \pm 1.28$)$ indicates the excess of recessive genes with increasing position due to positive value of $h^{2}(1.54 \pm 0.99)$. Unequal values of $\mathrm{H}_{1}$ and $\mathrm{H}_{2}$ illustrate unbalanced allocation of positive and negative genes as confirmed by $\mathrm{H}_{2} / 4 \mathrm{H}_{1}$ ratios $(0.13)$ in $F_{1}$ generations. According to the number of the genes that control the trait ratio $\left(K=h^{2} / \mathrm{H}_{2}\right)$, the value was 0.32 , also showed that this method is not suitable for the detection of how many genes control the trait for absence dominance. Frequencies of dominant and recessive alleles' ratio $\left(\mathrm{H}_{2} / 4 \mathrm{H}_{1}\right)$, the detection of 0.13 revealed that recessive and dominant alleles are not equal. $\mathrm{F}$ value is negative, showing that dominant alleles are little than recessive alleles. $\mathrm{KD} / \mathrm{KR}$, estimates for the ratio of dominance to recessive genes in the parents, is determined as 0.19 , confirming this. Narrow sense heritability $\left(h^{2} n\right)$ is 0.44 and broad sense heritability $\left(h^{2} b\right)$ is 0.94 (Table 5). Heritability in broad and narrow sense for the number of bolls was high with reasonable genetic variation. Murtaza (2005) and Desalegn et al. (2009) were reported similar findings. However, these results do not get support from the finding of Kanopiya and Fursow (1981). This suggested that major part of the total phenotypic variance was additive.

$\mathrm{Wr} / \mathrm{Vr}$ graph for $\mathrm{F}_{1}$ number of bolls is presented in Fig. 1. The $\mathrm{Wr} / \mathrm{Vr}$ (Fig. 1) and the dominance proportion (Table 6) for $F_{1}$ number of bolls, displayed that regression line passing through the $\mathrm{Wr}$ axis above the origin; thus, indicating partial dominance with additive type of gene action. When regression line of Wr graph intersects the Yaxis on the positive side, meaning that partial dominance in population is created in terms of number of bolls. Theoretical dominance coefficient $(\mathrm{r}=-0.69)$ is negative, showing that enhancing trait is the dominant alleles and parents, that produce a high number of bolls and dominant genes. This result indicates that 'Stoneville-453', which has the highest number of bolls per plant, has the most dominant genes (Fig. 1). This is also confirmed by 'Stoneville-453' parent, which has the highest dominance proportion (0.63) and the least distance (11.69) from origin of what (Table 6). 'Giza-45' has more recessive genes (Fig. 1). 'Giza-45', which has the lowest number of bolls per plant, has the lowest dominance proportion $(-0.03)$ and the greatest distance (24.97) from origin (Table 6). As regards the array points on the regression line, 'Stoneville- 453 ' followed by 'Paum-15' and 'Delcerro' showed maximum dominant genes due to the highest dominance proportion (Table 6) and their closest position to the origin, while 'Giza-45', 'Fantom' and 'Nazilli-84S' possessed recessive genes due to the smallest dominance proportion $(<0.16)$ and their distant position from the origin (Fig.1 and Table 6). These results get supported byfinding of Kumareson et al. (2000). Subhan et al. (2001), Leidi (2003), Mert et al. (2003), Khan et al. (2009), Paramjith Singh et al. (2009), Abd-El-Haleem et al. (2010), Deepika (2011) who also recorded additive type of gene action with partial dominance for the number of bolls, while the findings of Gamal et al. (2009) was not in line with present results as they mentioned that over-dominance type of gene action and the findings of Bertini et al. (2001), Kiani et al. (2007), Ramezani-Moghaddam (2003), Khan et al. (2005), Mei $e t$ al. (2006) were not in line with present results as they mentioned that non-additive type of gene action was responsible for inheritance of number of bolls. The differences with respect to phenotypic manifestation of the number of bolls might be due to different cultivars used under different agro-climatic conditions. 


\section{Lintpercentage (\%)}

The genetic components of variance were significant while $\mathrm{h}^{2}$ was non-significant (Table 5) for $\mathrm{F}_{1}$ lint percentages. The $\mathrm{H}_{1}$ and $\mathrm{H}_{2}$ parameters were much lower than $\mathrm{D}$ parameter. Additive component (D) exceeded dominance components $\left(\mathrm{H}_{1}\right.$ and $\left.\mathrm{H}_{2}\right)$. $\left(\mathrm{D}-\mathrm{H}_{1}\right)$ was 8.08 and GCA/SCA was 29.45 (Table 1) which confirm the hypothesis that the additive component is more dominant than the dominance component. Similar findings were reported by Rady et al. (1999), Baloch et al. (2000), Pradeep and Sumalini (2008), Deepika (2011). The average degree of dominance $\left(\sqrt{H_{1 / D}}=0.58\right)$ was being less than 1 , suggesting partial dominance with additive type of gene action. $\mathrm{F}$ with significant negative value $(-7.21 \pm 1.481)$ revealed that the recessive genes were more frequent than dominant and were in a decreasing position as confirmed by $h^{2}(-0.25 \pm 0.357)$. Unequal values of $H_{1}$ and $H_{2}$ illustrated unbalanced allocation of positive and negative genes as confirmed by $\mathrm{H}_{2} / 4 \mathrm{H}_{1}$ ratios $(0.19)$ in $\mathrm{F}_{1}$ generations. How many genes controls the trait ratio $\left(\mathrm{K}=\mathrm{h}^{2} / \mathrm{H}_{2}\right),-0.17$ detection, showed that this method is not suitable for the detection of how many genes controls the trait for absence dominance. Frequencies of dominant and recessive alleles ratio $\left(\mathrm{H}_{2} / 4 \mathrm{H}_{1}\right)^{\prime} \mathrm{s}$, the value was 0.19 , revealed that recessive and dominant alleles are not equal. $\mathrm{F}$ value is negative, showing that dominant alleles are fewer than recessive alleles. $\mathrm{KD} / \mathrm{KR}$, the rate of recessive alleles of dominant alleles, is determined as 0.33 , suggesting that there is more recessive genes frequency than dominance genes frequency. Narrow sense heritability $\left(h^{2} n\right)$ is 0.48 and broad sense heritability $\left(\mathrm{h}^{2} \mathrm{~b}\right)$ is 0.88 (Table 5$)$. Heritability in broad and narrow sense for the lint percentage was high with reasonable genetic variation. This suggested that major part of the total phenotypic variance was additive. Al-Jibouri et al. (1958), Desalegn et al. (2009) were reported similar results.

$\mathrm{Wr} / \mathrm{Vr}$ graph for $\mathrm{F}_{1}$ lint percentage is shown in Fig. 2. The $\mathrm{Wr} / \mathrm{Vr}$ and the dominance proportion (Table 6) for $\mathrm{F}_{1}$ lint percentage, displayed that regression line passing through the Wr axis above the origin; thus, indicating partial dominance with additive type of gene action. Significant negative correlation coefficient $(r=-0.94)$, between $(\mathrm{Wr}+\mathrm{Vr})$ and parental means, indicated that the parents containing dominant genes (Fig. 2) were responsible for the increased lint percentage in $F_{1}$ generation. This position indicates that 'Nazilli-84S' has the highest lint percentage and the most dominant genes (Fig. 2). In addition, this is also confirmed by 'Nazilli-84S' parent, which has the highest dominance proportion (0.82) and the least distance (4.32) from origin (Table 6). 'Giza-45' has the lowest dominance proportion $(-0.27)$ and the greatest distance (15.13) from origin (Table 6), shows that 'Giza-45' has more recessive genes (Fig. 2). From the position of array points on regression line, 'Nazilli-84S', 'Stoneville-453' and 'Delcerro' had maximum dominant genes by having dominance proportion (Table 6) and being nearer to the origin, while the cultivars 'Giza-45', 'Paum-15' and 'Fantom' are being away from the origin due to the lowest dominance proportion $(<0.25)$ depicted recessive gene action for the lint percentage. The finding of McCarty et al. (2004), Ahmad et al. (2003), Yuan et al. (2005), Aguiar et al. (2007) and Ali and Awan (2009) who also recorded additive type of gene action with partial dominance for the lint percentage supported these results. However, the results of Basal and Turgut (2005), Iqbal et al. (2005), Mei et al. (2006), Esmail (2007) and Gamal et al. (2009) were not in line with present results as they mentioned that nonadditive type of gene action was responsible for inheritance of lint percentage. The differences with respect to phenotypic manifestation of the lint percentage might be due to different cultivars used under different agro-climatic conditions.

\section{Seed-cotton yield ( $\left.\mathrm{kg}_{\mathrm{b}} \mathrm{ha}^{-1}\right)$}

Regarding genetic components of variance in $\mathrm{F}_{1}$ crosses, seed-cotton yield revealed that the additive (D), dominance $\left(\mathrm{H}_{1}\right.$ and $\left.\mathrm{H}_{2}\right), \mathrm{F}$, environmental $(\mathrm{E})$ component of variation were significant (Table 6). Dominance components $\left(\mathrm{H}_{1}\right.$ and $\mathrm{H}_{2}$ ) exceeded additive components (D). (D-H $\left.\mathrm{H}_{1}\right)$ is taking the value of -423.97 and GCA/SCA is taking the value of 0.63 (Table 1) which confirm the hypothesis that the dominant component is more dominant than the additive component. These results was supported by the finding of Basal and Turgut (2005), Khan et al. (2005), Esmail (2007), Aguado et al. (2008), Gamal et al. (2009), Khan and Hasan (2011) and Deepika (2011). The average degree of dominance $\left(\sqrt{H_{1 / D}}=1.17\right)$ was being more than 1 , suggesting dominance type of gene action with overdominance. $F$ with significant negative value $(859.68 \pm 62.136)$ revealed that the recessive genes were more frequent than dominant and were in an increasing position as confirmed by $h^{2}(1120.82 \pm 152.759)$. Unequal values of $\mathrm{H}_{1}$ and $\mathrm{H}_{2}$ illustrated unbalanced allocation of positive and negative genes as confirmed by $\mathrm{H}_{2} / 4 \mathrm{H}_{1}$ ratios $(0.20)$ in $F_{1}$ generations. How many genes controls the trait ratio $\left(\mathrm{K}=\mathrm{h}^{2} / \mathrm{H}_{2}\right), 0.88$ detection, showed that this method is not suitable for the detection of how many genes controls the trait. Frequencies of dominant and recessive alleles ratio $\left(\mathrm{H}_{2} / 4 \mathrm{H}_{1}\right)$ 's, the value was 0.20 , revealed that recessive and dominant alleles are not equal. $\mathrm{F}$ value is positive, showing that recessive alleles are fewer than dominant alleles. $\mathrm{KD} / \mathrm{KR}$, the rate of recessive alleles of dominant alleles, is determined as 0.52, suggesting that there is not equal dominant and recessive alleles and there may more recessive genes frequency than dominance genes frequency. Narrow sense heritability $\left(h^{2} n\right)$ is 0.32 and broad sense heritability $\left(\mathrm{h}^{2} \mathrm{~b}\right)$ is 0.78 (Table 5). Heritability in broad and narrow sense for seed-cotton yield was middle with reasonable genetic variation. This suggested that major part of the total phenotypic variance was dominant. The finding of Esmail et al. (1999), Kumaresan et al. (2000), Khan and Hassan (2011) who recorded high heritability for seed-cotton yield, supported these results.

$\mathrm{Wr} / \mathrm{Vr}$ graph for $\mathrm{F}_{1}$ seed-cotton yield is shown in Fig. 3. The $\mathrm{Wr} / \mathrm{Vr}$ and the dominance proportion (Table 6 ) for $\mathrm{F}_{1}$ seed-cotton yield, displayed that regression line intercepted the $\mathrm{Wr}$ axis below the origin point indicating over dominance. Significant negative correlation coefficient $(r=-$ $0.82)$ between $(\mathrm{Wr}+\mathrm{Vr})$ and parental means indicated that the parents containing dominant genes (Fig. 1) were responsible for the increased seed-cotton yield in $F_{1}$ generation. This position indicated that 'Stoneville-453' has 


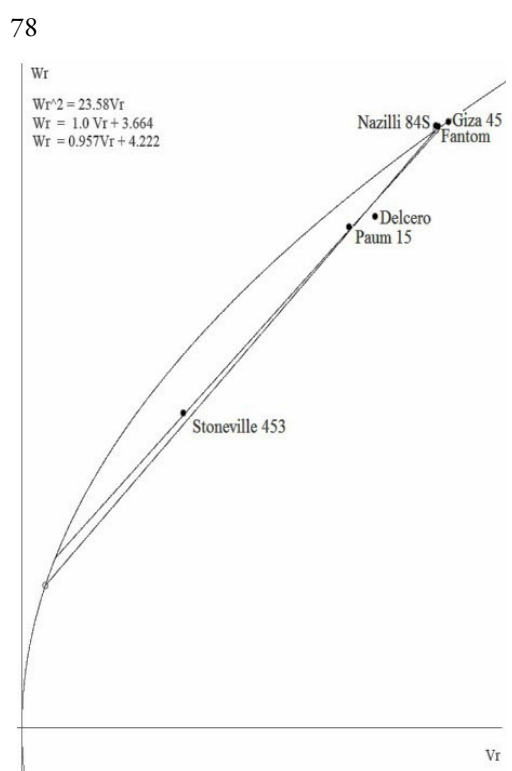

Fig. 1. Wr/Vr Graph for $F_{1}$ Number of Bolls

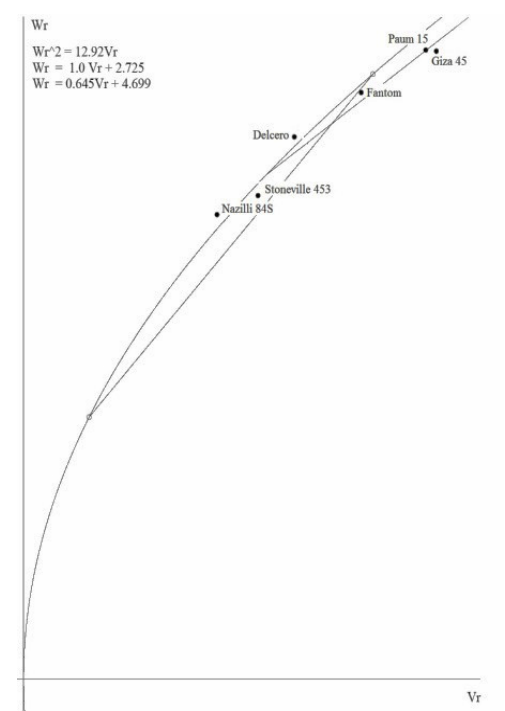

Fig. 2. Wr/Vr Graph for $F_{1}$ Lint Percentage

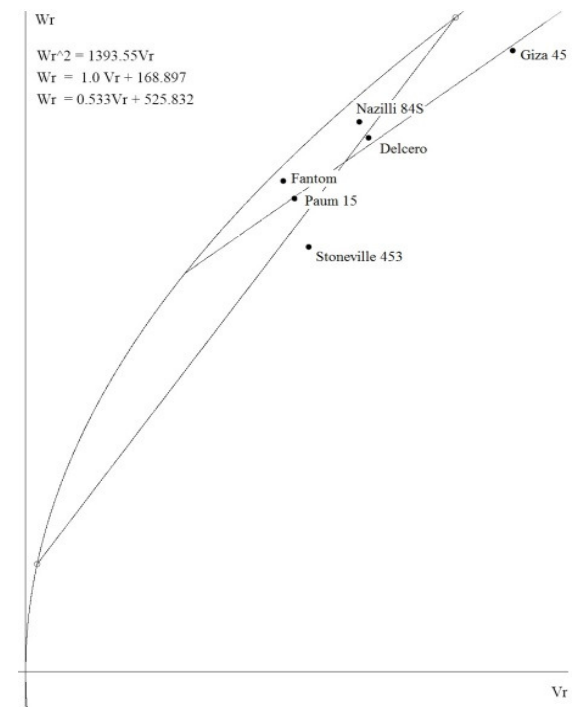

Fig. 3. Wr/Vr Graph for $F_{1}$ Seed-Cotton Yield the highest seed-cotton yield (Table 6) and the most dominant genes (Fig. 3). 'Stoneville-453' parent has the highest dominance proportion (0.87) and the least distance (191.61) from the origin (Table 9), a show 'Stoneville-453' has more dominant genes than which do. 'Giza- 45 ' has the lowest dominance proportion (-0.28) and the greatest distance (2423.63) from origin (Table 9), shows that 'Giza$45^{\prime}$ has more recessive genes (Fig. 3). From the of array points on the regression line, 'Stoneville-453', 'Paum-15' and 'Fantom' had maximum dominant genes by having dominance proportion (Table 6) and being nearer to the origin, while the cultivars 'Giza-45', 'Nazilli-84S' and 'Delcerro' are being away from the origin due to lowest dominance proportion $(<0.34)$ depicted recessive gene action for the seed-cotton yield. These results were similar to the finding of Kar et al. (2001), Iqbal et al. (2005), Talaat (2006), Gamal et al. (2009), who also presented overdominance type of gene action for seed-cotton yield. On the contrary to these results, Baloch et al. (2000), Kapoor (2000), Subhan et al. (2001), Leidi (2003), McCarty et al. (2004), Lukonge (2005), Wu et al. (2006), Aguiar et al. (2007), Lukonge et al. (2008), Khan et al. (2009) recorded additive type of gene action for the seed-cotton yield. The differences with respect to phenotypic manifestation of the seed-cotton yield might be due to different cultivars used under different agro-climatic conditions.

\section{Conclusions}

Additive and dominance components were found significant for the investigated traits, but in $F_{1}$ crosses, the investigated traits were controlled by additive gene action. Parents 'Paum-15' and 'Stoneville-453' were greater for the number of bolls and the seed cotton yield; 'Stoneville-453' and 'Nazilli-84S' for the lint percentages. 'Paum-15' $x$ 'Stoneville-453'; 'Stoneville-453' x 'Nazilli-84S'; 'Stoneville453' x 'Fantom'; 'Stoneville-453' x 'Delcerro' and 'Stoneville-453' x 'Giza-45' diallel crosses can be considered as greater cross combinations for the number of bolls; 'Paum-15' x 'Nazilli-84S', 'Stoneville-453' x 'Fantom',
'Nazilli-84S’ x 'Delcerro' and 'Nazilli-84S’ x 'Giza-45' diallel crosses for the lint percentages; 'Paum-15' x 'Stoneville-453', 'Paum-15' x 'Nazilli-84S', 'Stoneville-453' x 'Nazilli-84S', 'Stoneville-453' x 'Fantom', 'Stoneville-453' x 'Delcerro', 'Stoneville-453' x 'Giza-45', 'Nazilli-84S’ x 'Fantom' and 'Nazilli-84S' $x$ 'Delcerro' diallel crosses for the seed-cotton yield. Bolls per plant and the lint percentage traits were effective in the control of additive type of gene action with partial dominance, and had high broad and narrow sense heritability values. These results suggest that selection in the early segregating generations may be effects and the pedigree method selection may be employed to achieve genetic progress. However, the seed-cotton yield was effective in the control of dominance, type of gene action with overdominance, had middle broad and narrow sense heritability values. These results suggest that the selection in later segregating generations may be effects and mass selection have to be effective for the improving of high-yielding varieties of cotton. The 'Stoneville-453' population indicated the possibilities of prompt and effective improvements in the number of bolls per plant and the seed-cotton yield attributing traits.

\section{Acknowledgements}

The study was supported by Dicle University grant, Faculty of Agriculture, Department of Field Crops.

\section{References}

Abd El-Haleem SHM, Metwali EMR, Al-Felaly AMM (2010). Genetic analysis of yield and its components of some Egyptian cotton (Gossypium barbadense L.) varieties. World J Agric Sci 6:615-621.

Aguado A, De Los Santos B, Blanco C, Romero F (2008). Study of gene effects for cotton yield and Verticillium wilt tolerance in cotton plant (Gossypium hirsutum L.). Field Crops Res 107:78-86. 
Aguiar PA, Penna JCV, Freire EC, Melo LC (2007). Diallel analysis of upland cotton cultivars. Crop Breed Appl Biotechnol 7:353-359.

Ahmad S, Iqbal MZ, Ahmad S, Sadiq MA, Khan N (2003). Genetic Analysis of Morphological Characteristics and Seed Oil Content of Cotton (Gossypium hirsutum L.). OnLine J Biol Sci 3:396-405.

Ahuja SH, Tuteja OP (2000). Heterosis and combining ability for yield and its component traits in Upland cotton. J Cotton Res Devel 14(2):138-142.

Ali MA, Awan SI (2009). Inheritance pattern of seed and lint traits in cotton (G. hirsutum L.). Int J Agri Bio 11(1):4448.

Al-Jibouri HA, Miller PA, Robinson HF (1958). Genotypic and environmental variances and conveniences in upland cotton crosses of inter-specific origin. Agron J 50:623-636.

Baker JL, Verhalen LM (1975). Heterosis and combining ability for several agronomic and lint properties among selected lines of upland cotton. Cotton Grow Rev 52:209223.

Baloch MJ (1995). Combining Ability Estimates in $5 \times 5$ Diallel Intra Hirsutum Crosses. Pakistan J Bot 27(1):121126.

Baloch MJ, Lakho AR, Bhutto HU, Memon AM, Panhwar GN, Soomro AH (2000). Estimates of combining ability and genetic parameters for yield and fiber traits in upland cotton. Pak J Biol Sci 3(7):1183-1186.

Basal H, Turgut I (2005). Genetic analysis of yield components and lint strength in upland cotton $(G$. hirsutum L.). Asian J Plant Sci 4:293-298.

Bertini CHCDM, Silva FPD, Nunes RDP, Santos JHRD (2001). Gene action, heterosis and inbreeding depression of yield characters in mutant lines of upland cotton. Pesq Agrop Brasileria 36:941-948.

Bhardwaj RP, Kapoor CJ (1998). Genetics of yield and its contributing traits in upland cotton (Gossypium hirsutum L.). Proceedings of the World Cotton Research Conference-2, Athens, Greece, September 6(12):214-216.

Cheatham CC, Jenkins JN, McCarty JC, Watson CE, Wu J (2003). Genetic variances and combining ability of crosses of American cultivars, Australian cultivars, and wild cottons. J Cott Sci 7:16-22.

Deepika M (2011). Genetic studies in Gossypium barbadense L. cotton for productivity. MSc Agriculture, genetics and plant breeding. Dept Genetics and Plant Breeding, Dharwad Univ Agri Sci, DHARWAD-580.

Desalegn Z, Ratanadilok N, Kaveeta R (2009). Correlation and Heritability for Yield and Fiber Quality Parameters of Ethiopian Cotton (Gossypium hirsutum L.) Estimated from 15 (diallel) Crosses. Kasetsart J (Nat Sci) 43:1-11.

El-Mansy YM, Rokia MH, Abdel-Salam ME (2010). Estimation of Genetic Components and Genetic Divergence in Diallel Hybrids of Cotton. J Agric Res Kafer El-Sheikh Univ 36(1):17-32.
EL-Refaey RA, Abd El-Razek UA (2013). Generation Mean Analysis for Yield, its Components and Quality Characteristics in Four Crosses of Egyptian Cotton (Gossypium barbadense L.). Asian J Crop Sci 5:153-166.

Esmail RM (2007). Genetic analysis of yield and its contributing traits in two intra specific cotton crosses. J Appl Sci Res 3:2075-2080.

Esmail RM, Handawy FA, Rady FS, Hamid AM (1999). Genetic studies on yield and yield components in one inter and two intra specific crosses of cotton. Egypt J Agron 21:37-51.

Gamal IAM, Abd-El-Halem SHM, İbrahim EMA (2009). A Genetic Analysis of Yield and its Components of Egyptian Cotton (Gossypium barbadense L.) Under Divergent Environments. Am-Euras. J Agric Environ Sci 5(1):05-13.

Griffing B (1956). Concept of general and specific combining ability in relation to diallel crossing systems. Aust J Biol Sci 9:463-493.

Hayman BI (1954a). The theory and analysis of diallel crosses. Genet 39:789-809.

Hayman BI (1954b). The analysis of variance of diallel cross. Biometrics 10:235-245.

Hayman BL (1958). The theory and analysis of diallel crosses II. Genetics 43:63-85.

Iqbal MRSA, Khan K, Hayat, Noor-ul-Islam Khan (2005). Genetic variation and combining ability for yield and fiber traits among cotton Fr hybrid population. J Biol Sci 5(6):713-716.

Jinks JL (1954). The analysis of continuous variation in a diallel cross of Nicotiana rustica varieties. Genetics 39:767788.

Jinks JL (1956). The $F_{2}$ and back cross generation from set of diallel crosses. Heredity 10:1-30.

Kanopiya SP, Fursow VN (1981). Determining the Breeding Value of Cotton on Fruiting and Yield. Plant Breeding Abstract 36:570.

Kapoor A (2000). Inheritance Studies of Quantitative Characters In Upland Cotton (Gossypium hirsutum L.). Proceedings of The World Cotton Research Conference 2:211-213. Athens, Greece.

Kar MBB, Patro CR, Sahoo, Patel SN (2001). Response of hybrid cotton to moisture stress. Indian J Plant Physiol 6(4):427-430.

Khan NU, Hassan G, Kumbhar MB, Ghaloo SH (2005). Combining ability analysis for morphological and yield traits in intra- $G$. hirsutum crosses. SAARC J Agric 3:211-232.

Khan NU, Hassan G, Kumbhar MB, Parveen A, Aiman U, Ahmad W, Shah SA, Ahmad S (2007). Gene action of seed traits and oil content in upland cotton ( $G$. hirsutum L.). Sabrao J Breed Genet 39:17-30.

Khan NU, Hassan G, Marwat KB, Farhatullah, Kumbhar MB, Parveen A, Aiman U, Khan MZ, Soomro ZA (2009). Diallel analysis of some quantitative traits in G. hirsutum L. Pak J Bot 41(6):3009-3022. 
80

Khan NU, Hassan G (2011). Genetic effects on morphological and yield traits in cotton (Gossypium hirsutum L.). Span J Agric Res 9(2):460-472.

Khan SA, Khan N, Mohammad F, Ahmad M, Khan IA, Bibi Z, Khan IU (2011). Combining Ability Analysis In Intraspecific $F_{1}$ Diallel Cross Of Upland Cotton. Pak J Bot 43(3):17191723.

Khan NU (2013a). Diallel analysis of cotton leaf curl virus $(\mathrm{CLCuV})$ disease, earliness, yield and fiber traits under CLCuV infestation in upland cotton. AJCS 7(12):19551966.

Khan NU (2013b). Combining Ability Analysis in Intra Specific $F_{1}$ Diallel Cross of Upland Cotton. Scientific Papers Series A Agronomy 56:289-295.

Kiani G, Nematzadeh GA, Kazemitabar SK, Alishah O (2007). Combining ability in cotton cultivars for agronomic traits. Intl J Agric Biol 9(3):521-522.

Kumaresan D, Ganesan J, Ashok S (2000). Genetic analysis of quantitative traits in cotton ( $G$. hirsutum L.). Crop Res Hissar 19:481-484.

Leidi EO (2003). Combining Ability of Yield and Yield Components In Upland Cotton (Gossypium hirsutum L.) Under Drought Stress Conditions. Word Cotton Research Conference 3, Abstracts of Paper and Poster Presentations. S.33.7. Cape Town. South Africa.

Lukonge EP (2005). Traitization and diallel analysis of commercially planted cotton ( $G$. hirsutum L.) germplasm in Tanzania. PhD Dissertation. The Free State Univ, South Africa.

Lukonge EP, Labuschagne MT, Herselman L (2008). Combining ability for yield and fibre traitistics in Tanzanian cotton germplasm. Euphytica 161:383-389.

Mather K, Jinks JL (1971). Biometrical Genetics. Ed. Chapman \& Hall Ltd, London $2^{\text {nd }}, 38 \mathrm{p}$.

Mather K, Jinks JL (1977). Introduction to Biometrical Genet. Ed. Chapman \& Hall Ltd. London 1 ${ }^{\text {st. }}$, 73-80 p.

Mather K, Jinks JL (1982). Introduction to Biometrical Genet. Ed. Chapman \& Hall Ltd., London.

McCarty JC, Jenkins JN, Wu J (2004). Primitive accession derived germplasm by cultivar crosses as sources for cotton improvement. II. Genetic effects and genotypic values. Crop Sci. 44:1231-1235.

Mei YJ, Ye ZH, Li-Li Z (2006). Genetic analysis for $F_{1}$ yield traits with conditional approach in island cotton (Gossypium barbadense L.). Acta Gene Sin 33:841-850.

Meredith RW, Brown SJ (1998). Heterosis and combining ability of cottons originating from different regions of the United States. J Cott Sci 2:77-84.

Mert M, Gencer O, Akiscan Y, Boyaci K (2003). Determination of superior parents and hybrid combinations in respect to lint yield and yield components in cotton Turk. J Agr 27:337-343.
Miller PA, Marani A (1963). Heterosis and combining ability in diallel crosses of upland cotton. G. hirsutum L. Crop Sci 3:646-649.

Murtaza N (2005). Study of gene effects for boll number, boll weight and seed index in cotton. J Central European Agri 6(3):255-262.

Paramjit Singh Mittal VP, Buttar GS, Brar KS (2009). Genetic variability association studies in upland cotton (Gossypium birsutum L.). J Pres Punjab Agri Univ 46(3-4):109-111.

Pradeep T, Sulamini K (2008). Genetic analysis of yield and its components in $G$. arboreum. J Indian Soc Cotton Improv 32:59-67.

Rady MS, Hendawy FA, Hamid AAA, Esrnail RM (1999). Combining ability of yield and yield components in cotton. Egyptian J Agron 21:53-66.

Ramezani-Moghaddam MR (2003). Investigation of General and Specific Combining Ability in Cotton Using Line $\mathrm{x}$ Tester Analysis. World Cotton Research Conference 3, Abstracts of Paper and Poster Presentations. P.S. 31.9. Cape Town, South Africa.

Simon SY, Kadams AM, Aliyu B (2013). Combining Ability Analysis in $\mathrm{F}_{1}$ Hybrids of Cotton (Gossypium species L.) by Diallel Method in Northeastern Nigeria. Greener J Agri Sci 3(2):090-096.

Subhan M, Khan HU, Ahmad R (2001). Population analysis of some agronomic and technological traitistics of Upland cotton (G. hirsutum L.) using diallel analysis. Pak J Biol Sci 1:120-123.

Talaat AR (2006). Genetic analysis of drought tolerance in Egyptian cotton (Gossypium barbadense L.). M.Sc. Thesis, Agron. Dept., Assiut University, Egypt.

Tuteja OP, Luthra P, Kumar S (2003). Combining ability analysis in upland cotton for yield and its components. Indian J Agric Sci 73(12):671-675.

Ukai Y (2006). DIAL98. User's Guide. Ver. 6. DIAL98. Japan. Whitehouse RNH, Thompson JB, Ribiero MAM (1958). Studies on the breeding of self pollinated cereals. The use of diallel cross analysis in yield prediction. Euphytica 7:147-169.

Wu J, Jenkins JN, McCarty JC, Wu D (2006). Variance component estimation using the additive, dominance, and additive $\mathrm{x}$ additive model when genotypes vary across environments. Crop Sci 46:174-179.

Yuan YL, Zhang TZ, Guo WZ, Pan JJ, Kohel RJ (2005). Diallel analysis of superior fiber quality properties in selected upland cotton. Acta Genetica Sinica 1:79-85. 